\title{
correspondence
}

\section{Scientists think too}

SiR,--Thank you for referring to my recent Presidential Address to the American Physical Society (28 April, page 759). However the irony implicit in your references to my address does not escape me. I disagree with you especially when you closely couple some of my words to "the recent frenzy to project science as still valuable".

Come off it. On rereading my address and listening to a recording $I$ find nothing frenetic about it. In fact I delivered the address in an old sweater. 1 figured that a President of the American Physical Society, nicknamed Willy, was not to be outdone by a President of the United States, named Jimmy. The tape tells me I got some laughs but mainly I was in dead earnest. Sure, scientists are thinkers but our public image is just that -and long hair too! If society is to reach a solution of its present horrendous problems it must permit the scientist to be more than thinker, consultant and adviser. It must let him be a doer in the sense of executive, manager, legislator all the way to trouble-shooter and fix-it man. Society seems to have forgotten what happened in the winning of World War II and is now wasting a potent resource. You delude the public and discourage students by harping on the image of the scientist as the thinker. It obscures the role the scientist can perform as man of action.

WilliaM A. Fowler

Past President,

American Physical Society,

Caltech, California

SIR,-While agreeing with the sentiment of your advocacy for the role that could be played by scientists in the affairs of the nation (28 April, page 759 ), your suggestion that the mass media should take it upon itself to act as a public relations vehicle for science is both a serious indictment of scientists, and a misconception of the role of the media.

Science is undoubtedly the most highly funded cultural activity of today, yet precious little if any of this funding is devoted to developing the communication talents of its practitioners. British scientists, in my experience as a programme producer, are no more nor less talented as broadcasters than any other group of pro- fessional people. They are certainly no more nor less perceptive about the affairs of the nation than say lawyers, historians, philosophers. Your proposal that the media create an image for scientists seems to be asking that the media take part in a cover-up campaign. You're asking us to hide a failure in the training of scientists.

You write that "very few scientists are allowed to express their own views in any extended way". I could quibble with your words "very few", but I would like to draw your attention to some science broadcasts you appear not to hear. For example, the fortnightly Scientifically Speaking on Radio 3 is the kind of programme you say is missing. In a year's broadcasts about 30 notable scientists (not to my mind "very few") take part usually in a 45 minute conversation. Through the questions of the interviewer, even the totally uninitiated yet intelligent listener is taken to the epistemological frontiers of science. Sydney Brenner, Leon van Hove, Nick Humphrey, D. T. Whiteside and B. F. Skinner-all participants in recent editions of Scientifically Speaking-falsify your general proposition that radio does badly in portraying the scientist as thinker. In broadcasting, what achieves impact is high programme standards, not saturation of the wavebands with merely adequate broadcasts mounted to present an image.

There also exists on Radios 3 and 4 another admirable vehicle for scientists as homo 'sapiens'- the scripted talk. I am not inundated with unsolicited ideas. You might well argue that we are too restrictive in allowing speakers the freedom to choose their topics. I would counter by drawing your attention to the long running Radio 3 series Personal View, transmitted on alternate Saturday evenings. In the course of four, 20-minute Personal View talks, the speaker is encouraged to reflect on topics of his own choice. Over the past three years, the three scientists who have given Personal View series have set a high standard for the others to come. Dauntingly, it seems, because many of those approached are put off by a brief that asks them to argue on topics that are in the public eye.

Surely scientists do have views, but why are they so often inhibited when offered a platform to expose their thoughts on issues outside their field of professional enquiry? Let's not have image-building. Broadcasters are not public relations men; let's have the real article.

$B B C$, London, $U K$

David Paterson

\section{T. H. Huxley, a self portrait}

SIR,-I found this self-portrait of T. H. Huxley among the effects of $\mathrm{Mr}$ W. D. Bradfield, assistant to Sir William de W. Abney, a former physics professor at Imperial College, best known for his researches in colour vision.

In his autobiography T. H. Huxley states that he inherited his faculty for drawing from his father but never received any formal training. Sir Julian Huxley considered his grandfather's sketches almost as finely executed as those of Leonardo da Vinci.

Bradfield photographed the drawing and the back of the photograph reads "photograph of pencil drawing of Professor Huxley. Drawn by Professor Huxley in Captain Abney's memo book". Abney joined the Science and Art Department, South Kensington in 1877 and Huxley resigned his appointment at the Royal School of Mines in 1885. The sketch was therefore probably drawn sometime during this period when Huxley was in his midfifties.

University of Surrey,

M. Davies

Guildford, UK

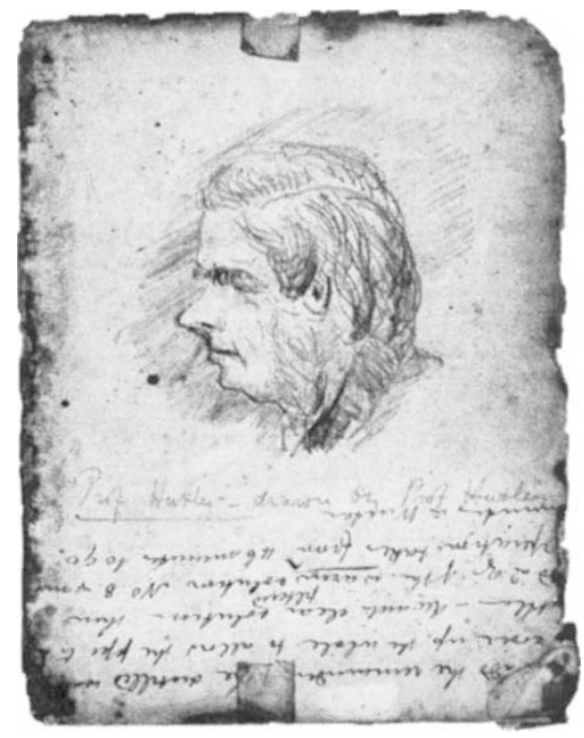

